\title{
Role of long non-coding RNAs in disease progression of early stage unmutated chronic lymphocytic leukemia
}

\author{
Renee C. Tschumper ${ }^{1}$, Tait D. Shanafelt ${ }^{3}$, Neil E. Kay ${ }^{4}$ and Diane F. Jelinek ${ }^{2,4}$ \\ ${ }^{1}$ Department of Immunology, Mayo Clinic, Rochester, MN, USA \\ ${ }^{2}$ Department of Immunology, Mayo Clinic, Scottsdale, AZ, USA \\ ${ }^{3}$ Department of Hematology/Oncology, Stanford University, Stanford, CA, USA \\ ${ }^{4}$ Department of Internal Medicine, Division of Hematology, Mayo Clinic, Rochester, MN, USA \\ correspondence to: Diane F. Jelinek, email: jelinek.diane@mayo.edu \\ Keywords: long non-coding RNA; chronic lymphocytic leukemia; unmutated immunoglobulin heavy chain variable region; \\ progression; early Rai stage \\ Received: October 27, $2018 \quad$ Accepted: December 12, $2018 \quad$ Published: January 01, 2019 \\ Copyright: Tschumper et al. This is an open-access article distributed under the terms of the Creative Commons Attribution License \\ 3.0 (CC BY 3.0), which permits unrestricted use, distribution, and reproduction in any medium, provided the original author and \\ source are credited.
}

\section{ABSTRACT}

Predicting disease progression in chronic lymphocytic leukemia (CLL) remains challenging particularly in patients with Rai Stage 0/I disease that have an unmutated immunoglobulin heavy chain variable region (UM IGHV). Even though patients with UM IGHV have a poor prognosis and generally require earlier treatment, not all UM IGHV patients experience more rapid disease progression with some remaining treatment free for many years. This observation suggests biologic characteristics other than known prognostic factors influence disease progression. Alterations in long non-coding RNA (IncRNA) expression levels have been implicated in diagnosis and prognosis of various cancers, however, their role in disease progression of early Rai stage UM CLL is unknown. Here we use microarray analysis to compare IncRNA and mRNA profiles of Rai 0/I UM IGHV patients who progressed in < 2 years relative to patients who had not progressed for $>5$ years. Over 1,300 IncRNAs and 940 mRNAs were differentially expressed (fold change $\geq 2.0$; p-value $\leq 0.05$ ). Of interest, the differentially expressed IncRNAs T204050, NR_002947, and uc.436+, have known associated genes that have been linked to CLL. Thus, our study reveals differentially expressed IncRNAs in progressive early stage CLL requiring therapy versus indolent early Rai stage UM CLL. These IncRNAs have the potential to impact relevant biological processes and pathways that influence clinical outcome in CLL.

\section{INTRODUCTION}

Chronic lymphocytic leukemia (CLL) remains a clinically heterogeneous disease despite recent advances in disease classification centered upon cellular and molecular markers. Prognostic models based on Rai stage, immunoglobulin heavy chain variable region mutation status (IGHV), cytogenetic abnormalities, gene mutations and expression of ZAP-70, CD38 and CD49d proteins have been developed and show efficacy in predicting disease outcome in some cases of CLL [1-10]. A recently developed CLL International Prognostic Index using age, clinical stage, TP53 status, IGHV mutation status, and serum $\beta 2$-microglobulin has been shown to better predict progression in early CLL $[2,11]$. Despite these advances, heterogeneity in clinical behavior remains incompletely explained, particularly as it concerns the variable rate of progression that exists in early stage Rai $(0 / \mathrm{I})$ patients with an unmutated (UM) IGHV. Although UM IGHV status has been shown to be a negative prognostic factor $[12,13]$, some patients experience rapid progression and early death while others live for many years without disease progression. This disparity suggests that there are currently unidentified biologic factor(s) which contribute 
to CLL disease heterogeneity and progression within the Rai 0/I UM subset of CLL patients.

Gene expression profiling and genome-wide association studies have identified important genes and alleles that may play a pathobiological role in CLL [14-17]. However, these studies have focused on protein-coding genes and well-known annotated genes. Protein-coding genes account for only $2 \%$ of the human genome but more than $70 \%$ of the genome is transcribed into non-coding RNA [18]. Accumulating evidence demonstrates some functionality for non-coding RNAs. For example, small non-coding micro-RNAs have been shown to function as post-transcriptional regulators and play a role in differentiation and development in various diseases including CLL [19-25]. More recently, a number of studies have shown that the more complex long noncoding RNAs (lncRNAs) also play an important role in both cell development and cancer [26-30].

LncRNAs are transcribed RNA molecules greater than 200 nucleotides long and have been traditionally defined as having no open reading frame, although many lncRNAs associate with ribosomes and may encode short peptides [31, 32]. Studies of lncRNA expression in B cell development $[33,34]$ indicate a role for lncRNAs in the pathogenesis and progression of $\mathrm{B}$ cell malignancies $[35,36]$. Indeed, there is evidence that IncRNAs can associate with clinical features in human acute and chronic leukemias allowing for discrimination of disease subtypes and clinical outcomes [37-45].

In this study, we used a microarray based approach to analyze the lncRNA and mRNA expression profiles of Rai 0/I UM CLL patients with progressive disease requiring therapy ( $\mathrm{PD}$; time to first treatment (TTT) $\leq 2$ years) compared to those with more stable, indolent disease (ID; TTT $\geq 5$ years). Our comprehensive profiling has allowed us to identify specific lncRNAs that are differentially expressed and may contribute to the clinical heterogeneity observed in this subset of CLL patients. Moreover, the data provide a crucial foundation for future studies investigating the utility of any of these lncRNAs to serve as biomarkers that may allow earlier prediction of disease progression.

\section{RESULTS}

LncRNA and mRNA expression profiles in early stage IGHV UM CLL patients with progressive versus indolent disease

LncRNA and mRNA expression profiling was performed on 34 PD and 29 ID Rai 0/I UM IGHV CLL samples using a microarray based approach (Table 1;
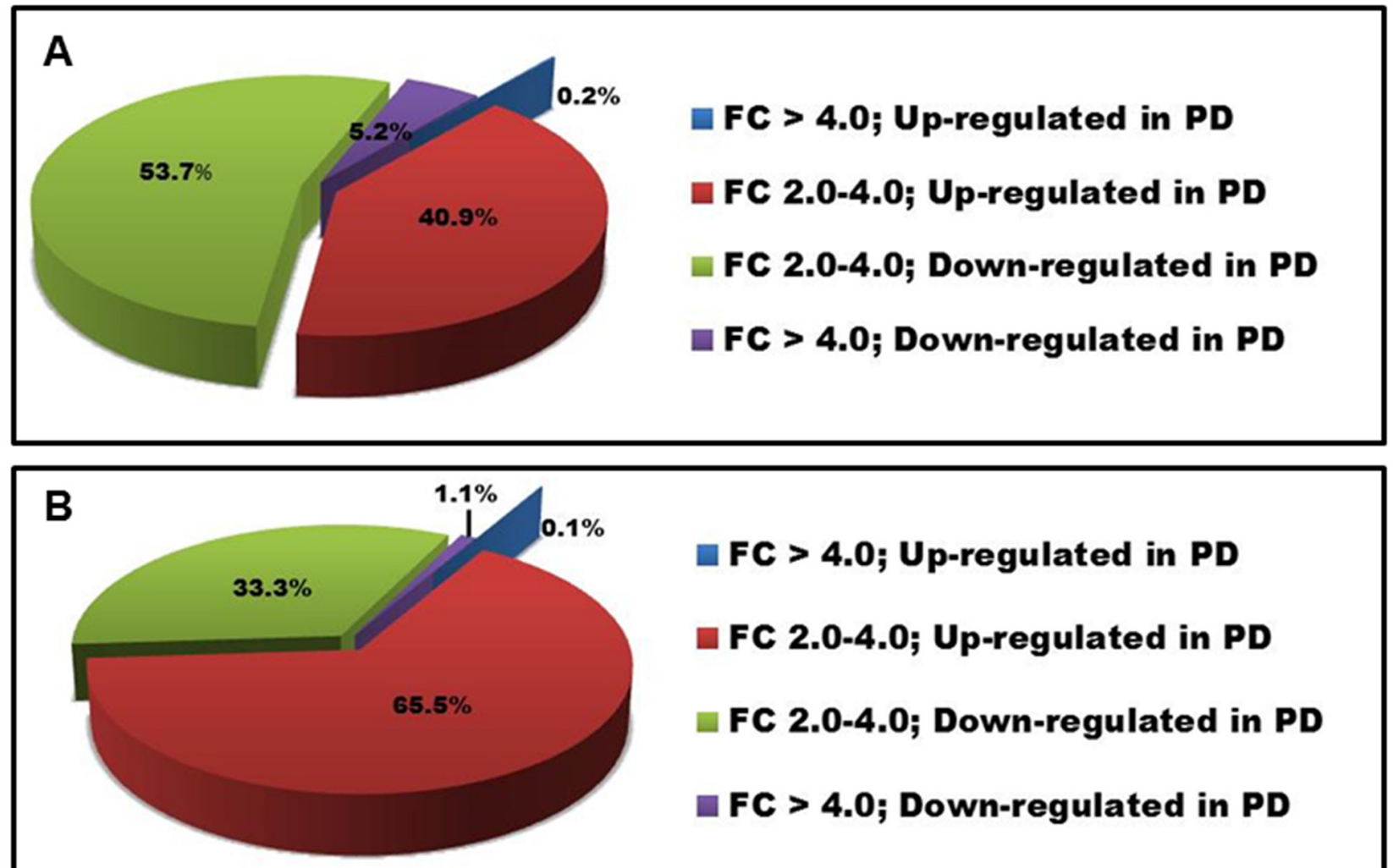

FC > 4.0; Up-regulated in PD

FC 2.0-4.0; Up-regulated in PD

FC 2.0-4.0; Down-regulated in PD

FC > 4.0; Down-regulated in PD

Figure 1: Distribution of differentially expressed IncRNAs and mRNAs in PD vs ID CLL. FC in (A) IncRNA and (B) mRNA expression. 
Supplementary Table 1). Of the 40,173 lncRNAs on the Arraystar Human IncRNA Array v4.0, 1,330 lncRNAs (3.3\%) were considered differentially expressed among PD compared to ID patients based on at least 12 Present or Marginal flags, a fold change $(\mathrm{FC}) \geq 2.0$ and a p-value $\leq 0.05$ (as calculated by the t-test) after normalization. False discovery rates (FDRs) were adjusted from all the p-values by the Benjamini-Hochberg method for multiple testing corrections (data accessible at NCBI GEO database, accession GSE123075). Overall, 547 (41\%) of differentially expressed lncRNAs were up-regulated in PD and $783(59 \%)$ were down-regulated in PD (Figure 1A). The most differentially expressed lncRNAs in PD versus ID were ENST00000416908 (up; FC 7.3) and T074942 (down; FC 13.5). Only 5.4\% (72/1330) of the differentially expressed lncRNAs had a $\mathrm{FC} \geq 4.0$. Of those, 69 were expressed at a higher level in ID samples while only 3 were expressed at a higher level in the PD samples (Figure 2; Table 2). Using the same Arraystar platform and criteria to analyze mRNA transcripts, 940 of 20,730 mRNAs $(4.5 \%)$ were differentially expressed with 617 (65.6\%) up-regulated in PD versus 323 (34.3\%) down-regulated in PD (Figures 1B and 3). The most differentially expressed mRNAs in PD vs ID were PCDHB2 (protocadherin beta 2; up-regulated; FC 4.1) and OR6K2 (olfactory receptor family 6 subfamily $\mathrm{K}$ member 2 ; down-regulated; FC 8.2) (data not shown; NCBI GEO database, accession GSE123075).

The differentially expressed lncRNAs were distributed across all chromosomes with 39.5\% located

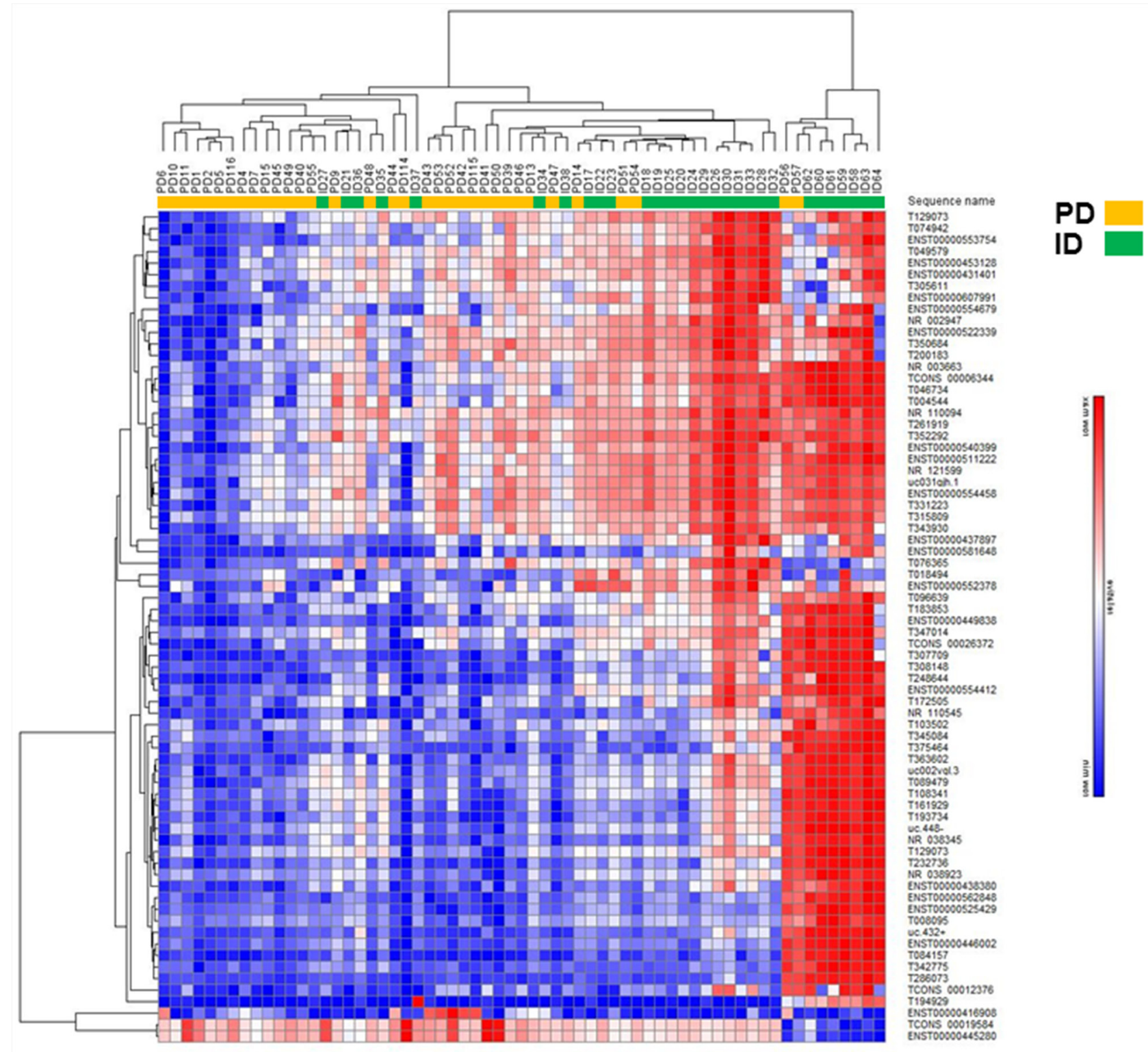

Figure 2: Hierarchical clustering analysis of differentially expressed IncRNAs in PD vs ID early stage CLL. Heatmap of lncRNAs differentially expressed by $\mathrm{FC} \geq 4.0$. 
on chromosomes 1, 2, 6, 7, 8 and 10 (Figure 4). Given that chromosome 12 occurs as a trisomy in $10-20 \%$ of CLL patients and is an indicator of intermediate risk [46], it was conceivable that those patients with trisomy 12 significantly impacted the lncRNA profile with respect to PD or ID CLL. However, when focusing on the trisomy 12 patients only, the differential expression of PD vs ID for those lncRNAs located on chromosome 12 with $\mathrm{FC} \geq$ 2.0 was retained (data not shown) thereby indicating that the extra copy of chromosome 12 in some patients did not underlie differential lncRNA expression.

LncRNAs can be classified into 5 broad categories based on genomic context and their relationship to protein coding genes [47]. This classification can provide insight into their possible functional roles. Of the 1,330 differentially expressed lncRNAs in this study,1,005 (76\%) were classified as antisense, bidirectional, intergenic, intronic, or sense overlapping of introns or exons with $43 \%$ being up-regulated in PD and 57\% down-regulated in PD across all categories (Figure 5). The majority (67\%) of differentially expressed lncRNAs were intergenic (located between annotated coding genes) with 272 intergenic lncRNAs up-regulated in PD and 401 down-regulated. Intergenic lncRNAs are more evolutionarily conserved, can be very tissue-specific and may exhibit active transcription as compared to other types of lncRNAs suggesting functionality [47]. The remaining $33 \%$ of classified lncRNAs are oriented in either a sense or antisense direction within exons or introns of protein coding genes and may still carry out a variety of biological roles.

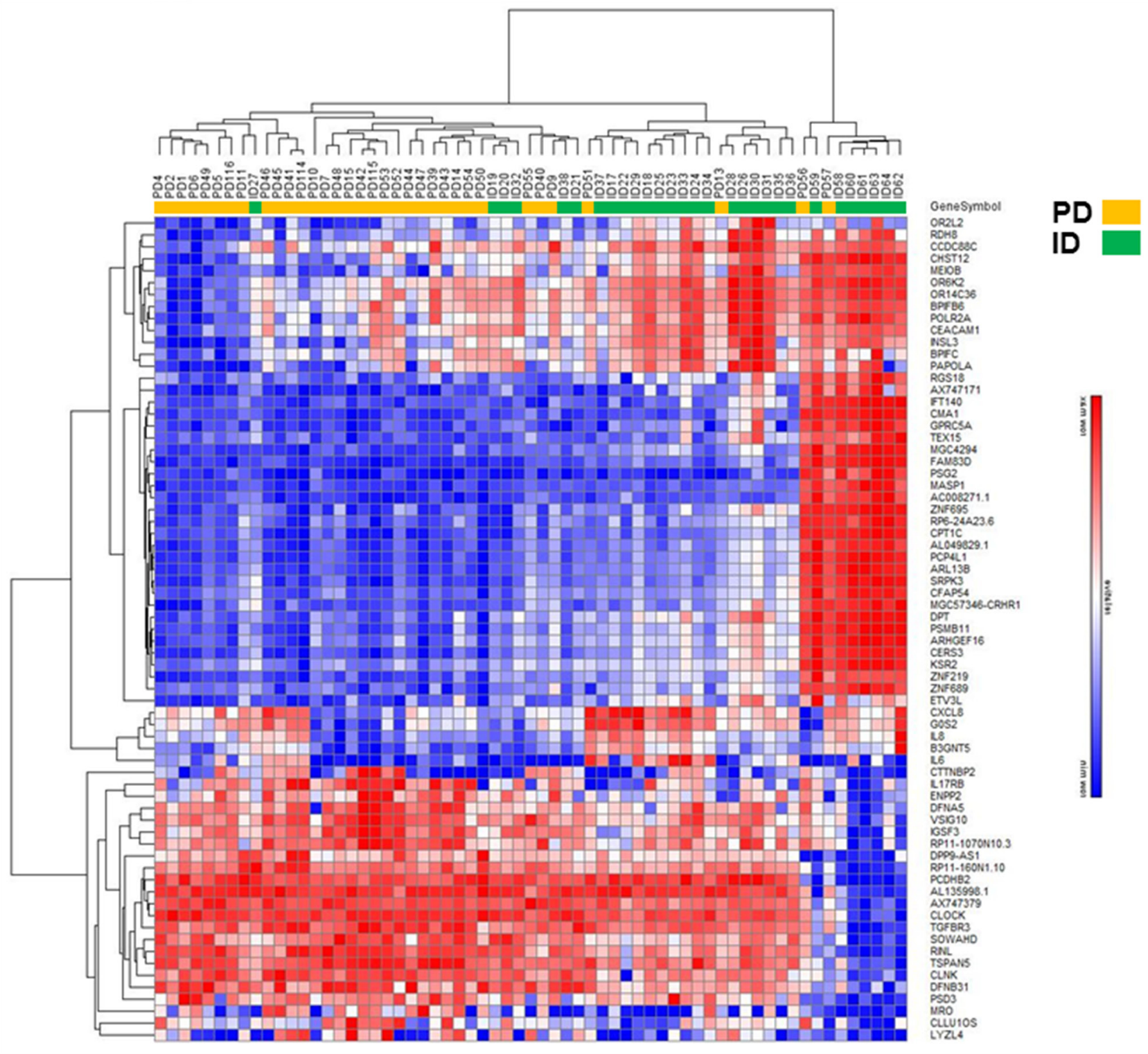

Figure 3: Hierarchical clustering analysis of differentially expressed mRNAs in PD vs ID early stage CLL. Heatmap of mRNAs differentially expressed by $\mathrm{FC} \geq 4.0$. 


\section{Gene ontology and pathway analysis}

Even though the exact target protein coding genes and the biological role of many lncRNAs are unknown, many play a regulatory role in the transcription of protein coding genes [48]. Therefore, the overall function of differentially expressed lncRNAs in PD vs ID samples may be suggested by the mRNA expression profiles of PD vs ID samples. Hence, Gene Ontology (GO) and Kyoto Encyclopedia of Genes and Genomes (KEGG) analysis of the biological processes and pathways associated with differentially expressed mRNAs was done. GO analysis revealed that mRNAs differentially expressed in PD vs ID CLL were linked with over 700 biological processes. The most enriched biological processes associated with up-regulated transcripts in PD samples involved multiple metabolic processes, translation and gene expression while down-regulated transcripts involved chemotaxis and cytokine metabolism and production (Figure 6). KEGG pathway enrichment analysis revealed 49 pathways associated with differentially expressed mRNAs. Pathways associated with up-regulated mRNA in PD were centered again on metabolism but the pathways associated with down-regulated mRNAs featured signaling pathways related to TNF, NF-kappa B, Toll-like receptors, and NOD-like receptors, all of which have been studied in the context of CLL pathophysiology (Figure 7) [49-51].

\section{Real-time quantitative PCR validation}

Thirty lncRNAs were selected for validation by realtime quantitative PCR (RT-qPCR) based on FC, associated or nearby protein coding genes, and/or relevance to CLL. Protein coding genes are considered associated if the

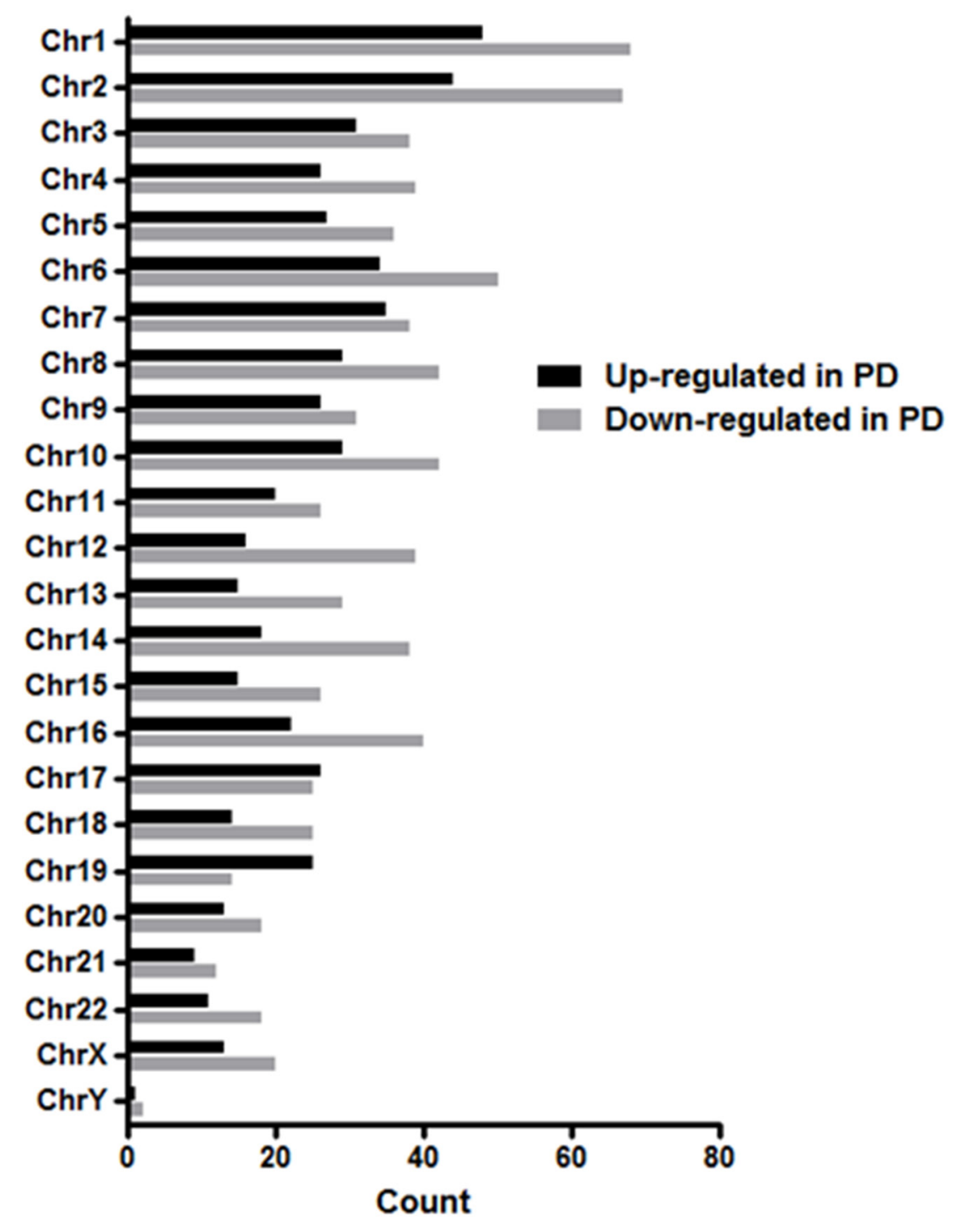

Figure 4: Chromosomal distribution of differentially expressed IncRNAs in PD vs ID early stage CLL. The differentially expressed lncRNAs with $\mathrm{FC} \geq 2.0$ were distributed across all chromosomes. 


\begin{tabular}{|c|c|c|}
\hline & $\begin{array}{c}\text { Progressive Disease } \\
(\text { PD })^{*} \\
(n=34)\end{array}$ & $\begin{array}{c}\text { Indolent Disease } \\
(\text { ID })^{* *} \\
(\mathbf{n}=29)\end{array}$ \\
\hline Age at Diagnosis, Minimum (yrs) & 42.1 & 36.2 \\
\hline Age at Diagnosis, Maximum (yrs) & 81.4 & 89.2 \\
\hline Age at Diagnosis, Median (yrs) & 54.0 & 63.4 \\
\hline TTT, Minimum (yrs) & 0.1 & 5.0 \\
\hline TTT, Maximum (yrs) & 1.8 & 10.3 \\
\hline TTT, Median (yrs) & 0.45 & 6.2 \\
\hline Rai 0 at Diagnosis (\# of Patients) & 13 & 22 \\
\hline Rai 1 at Diagnosis (\# of Patients) & 21 & 7 \\
\hline
\end{tabular}

${ }^{*}$ TTT $\leq 2$ yrs after diagnosis; ${ }^{* *}$ TTT $\geq 5$ yrs after diagnosis.

lncRNA is located within $1 \mathrm{~kb}$ of the promoter region of the gene(s). LncRNAs beyond $1 \mathrm{~kb}$ but within $300 \mathrm{~kb}$ are considered intergenic. Using a subset of samples from the original microarray cohort, 25 of the 30 lncRNAs followed the trend of the microarray analysis although only 20 of the 25 reached statistical significance (Supplementary Figure

1). Seven lncRNAs were selected on the basis of either
FC or association with protein-coding genes (Table 3; Supplementary Figure 2) and were subjected to further validation using an independent set of 10 CLL patients (5 PD and 5 ID). By microarray analysis, lncRNAs T347014 and T183853 were both down-regulated in PD CLL with FCs of 10.3 and 8.9 respectively. RT-qPCR validated those results with significantly down-regulated expression in

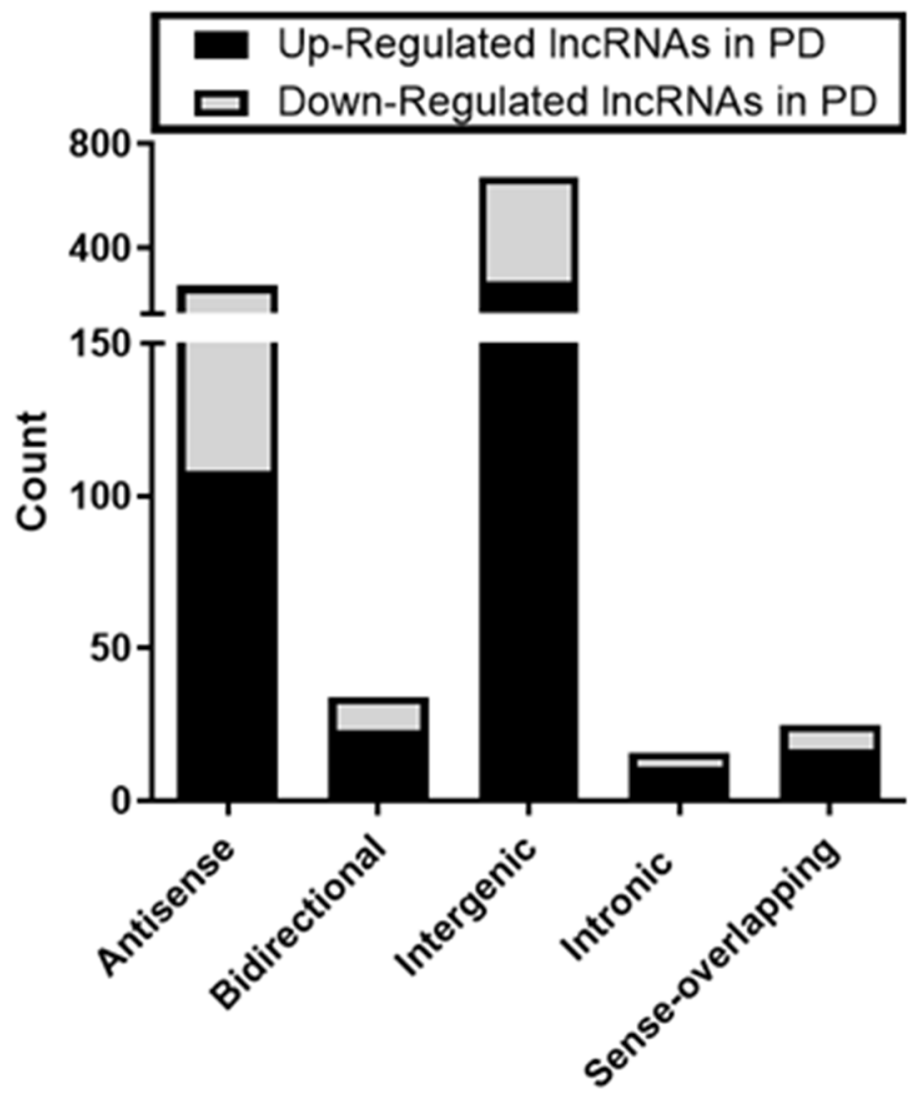

Figure 5: Types of differentially expressed IncRNAs in early stage PD vs ID CLL. 1005 of the 1330 lncRNAs could be classified based on relationships to protein coding genes. 
Table 2: LncRNAs differentially expressed in PD vs ID Rai 0/I UM CLL patients

\begin{tabular}{|c|c|c|c|c|c|c|c|}
\hline Sequence Name* & $\operatorname{Chr}( \pm)$ & FC & Relationship & Sequence Name & $\operatorname{Chr}( \pm)$ & FC & Relationship \\
\hline T074942 & $\operatorname{chr} 12(+)$ & 13.5 & Intergenic & Т0894791 & $\operatorname{chr} 12(+)$ & 5.7 & Intergenic \\
\hline ENST00000435766 2 & $\operatorname{chr} 7(-)$ & 11.0 & Intronic Antisense & $\mathrm{T}_{004544^{1}}$ & $\operatorname{chr} 1(+)$ & 5.7 & Intergenic \\
\hline Т347014 & $\operatorname{chr} 8(-)$ & 10.3 & Unknown & ENST00000525429² & $\operatorname{chr11(-)}$ & 5.6 & Intergenic \\
\hline ENST00000522339² & $\operatorname{chr} 8(+)$ & 9.4 & Intergenic & T261919 & $\operatorname{chr} 4(-)$ & 5.5 & Unknown \\
\hline $\mathrm{T} 183853^{1}$ & $\operatorname{chr} 2(+)$ & 8.9 & Intergenic & ENST00000562848² & $\operatorname{chr} 12(+)$ & 5.5 & Sense-Overlapping \\
\hline NR_1100943 & $\operatorname{chr} 7(+)$ & 8.7 & Intergenic & $\mathrm{T} 315809^{1}$ & $\operatorname{chr6}(-)$ & 5.3 & Intergenic \\
\hline T308148 ${ }^{1}$ & $\operatorname{chr6(-)}$ & 8.5 & Unknown & T375464 ${ }^{1}$ & $\operatorname{chrX}(+)$ & 5.2 & Unknown \\
\hline T307709 & $\operatorname{chr6(-)}$ & 8.4 & Intergenic & uc002vgl. $3^{6}$ & $\operatorname{chr} 2(-)$ & 5.1 & Intergenic \\
\hline NR_0029473 & $\operatorname{chr} 17(+)$ & 8.3 & Intergenic & ENST00000446002 & $\operatorname{chr} 1(-)$ & 5.1 & Intergenic \\
\hline ENST00000453128² & $\operatorname{chr} 1(-)$ & 8.2 & Intronic Antisense & NR_110545 & $\operatorname{chr} 21(-)$ & 5.1 & Intergenic \\
\hline Т049579¹ & $\operatorname{chr} 10(+)$ & 7.9 & Intergenic & $\mathrm{T} 129073^{1}$ & $\operatorname{chr} 16(+)$ & 5.1 & Intergenic \\
\hline ENST00000540399² & $\operatorname{chr} 12(-)$ & 7.9 & Intergenic & $\mathrm{T} 193734^{1}$ & $\operatorname{chr} 2(+)$ & 5.0 & Intronic Antisense \\
\hline ENST00000553754² & $\operatorname{chr} 14(-)$ & 7.9 & Intergenic & $\mathrm{T} 108341^{1}$ & $\operatorname{chr} 14(+)$ & 4.7 & Unknown \\
\hline ENST00000449838² & $\operatorname{chr} 2(-)$ & 7.7 & Intronic Antisense & NR_1215993 & $\operatorname{chr9}(+)$ & 4.7 & Intronic Antisense \\
\hline ENST00000554679² & $\operatorname{chr} 14(-)$ & 7.5 & Intronic Antisense & ENST00000552378² & $\operatorname{chr} 12(+)$ & 4.6 & Intergenic \\
\hline NR_003663 & $\operatorname{chr} 2(+)$ & 7.4 & Intergenic & ENST00000438380² & $\operatorname{chr} 9(+)$ & 4.6 & Intronic Antisense \\
\hline TCONS_00026372 & $\operatorname{chr} 18(+)$ & 7.3 & Intergenic & T076365¹ & $\operatorname{chr} 12(+)$ & 4.6 & Intergenic \\
\hline ENST00000416908 & $\operatorname{chr} 1(+)$ & 7.3 & Intergenic & $\mathrm{T} 331223^{1}$ & $\operatorname{chr} 7(+)$ & 4.6 & Intronic Antisense \\
\hline T3636021 & $\operatorname{chr9}(-)$ & 7.2 & Intergenic & ENST00000554412² & $\operatorname{chr} 15(-)$ & 4.5 & Intergenic \\
\hline ENST000004314012 & $\operatorname{chr6(-)}$ & 7.1 & Intergenic & $\mathrm{T} 161929^{1}$ & $\operatorname{chr} 18(+)$ & 4.5 & Unknown \\
\hline T096639 & $\operatorname{chr} 13(+)$ & 6.8 & Intergenic & T343930 1 & $\operatorname{chr} 8(+)$ & 4.5 & Unknown \\
\hline TCONS_00006344 & $\operatorname{chr} 3(+)$ & 6.7 & Intergenic & T084157¹ & $\operatorname{chr} 12(-)$ & 4.4 & Intergenic \\
\hline $\mathrm{T} 103502^{1}$ & $\operatorname{chr} 14(-)$ & 6.5 & Intergenic & ENST00000607991² & $\operatorname{chr} 22(+)$ & 4.4 & Intronic Antisense \\
\hline T046734 ${ }^{1}$ & $\operatorname{chr} 10(-)$ & 6.4 & Intergenic & TCONS_00012376 & $\operatorname{chr6(-)}$ & 4.4 & Intergenic \\
\hline uc. $432+^{5}$ & $\operatorname{chr} 18(+)$ & 6.4 & Intergenic & uc. $448-^{5}$ & $\operatorname{chr19}(-)$ & 4.3 & Intergenic \\
\hline ENST00000511222 2 & $\operatorname{chr} 4(+)$ & 6.2 & Intronic Antisense & $\mathrm{T}_{008095^{1}}$ & $\operatorname{chr} 1(+)$ & 4.3 & Intergenic \\
\hline $\mathrm{T} 350684^{1}$ & $\operatorname{chr8(-)}$ & 6.2 & Unknown & NR_038345 & $\operatorname{chr} 7(+)$ & 4.2 & Natural Antisense \\
\hline $\mathrm{T} 248644^{1}$ & $\operatorname{chr} 3(-)$ & 6.1 & Unknown & $\mathrm{T} 342775^{1}$ & $\operatorname{chr} 8(+)$ & 4.2 & Intergenic \\
\hline ENST00000437897² & $\operatorname{chr} 2(+)$ & 6.0 & Intronic Antisense & T1949291 & $\operatorname{chr} 2(-)$ & 4.2 & Intergenic \\
\hline $\mathrm{T} 345084^{1}$ & $\operatorname{chr} 8(-)$ & 6.0 & Intergenic & $\mathrm{T} 352292^{1}$ & $\operatorname{chr} 8(-)$ & 4.1 & Unknown \\
\hline $\mathrm{T} 232736^{1}$ & $\operatorname{chr} 22(-)$ & 5.9 & Unknown & ENST00000581648² & $\operatorname{chr} 18(-)$ & 4.1 & Intergenic \\
\hline uc031qjh. $1^{6}$ & $\operatorname{chr} 12(+)$ & 5.9 & Natural Antisense & TCONS_000195844 & $\operatorname{chr11(-)}$ & 4.0 & Intergenic \\
\hline $\mathrm{T} 305611^{1}$ & $\operatorname{chr} 6(+)$ & 5.9 & Sense-Overlapping & $\mathrm{T} 286073^{1}$ & $\operatorname{chr} 5(+)$ & 4.0 & Unknown \\
\hline $\mathrm{T} 172505^{1}$ & $\operatorname{chr19(-)}$ & 5.8 & Intergenic & ENST00000445280² & $\operatorname{chr9(-)}$ & 4.0 & Intergenic \\
\hline T018494 ${ }^{1}$ & $\operatorname{chr} 1(-)$ & 5.8 & Unknown & ENST00000554458² & $\operatorname{chr} 14(+)$ & 4.0 & Intergenic \\
\hline T200183¹ & $\operatorname{chr} 2(+)$ & 5.8 & Unknown & NR_038923 3 & $\operatorname{chr} 11(-)$ & 4.0 & Bidirectional \\
\hline
\end{tabular}

Only those lncRNAs with $\mathrm{FC} \geq 4.0$ are shown. $\mathrm{Chr}( \pm)$ indicates the genomic location on sense and antisense strands of human chromosomes. FC based on $\log 2$ changes. LncRNAs in bold are up-regulated in PD vs ID samples with all other lncRNAs expressed at $\geq 4$ fold higher levels in ID vs PD. * Indicates the source of the lncRNA sequence name. ${ }^{1}$ PMID:25599403; ${ }^{2}$ GENCODE; ${ }^{3}$ RefSeq (NCBI Reference Sequence Database); ${ }^{4}$ PMID:21890647; 5 PMID:15131266; 6 University of California Santa Cruz (UCSC) Known Genes dataset. 
PD CLL (Figure 8A). When looking at those differentially expressed lncRNAs with associated protein coding genes, ENST00000435766 (FC=11; associated mRNA RALA) and ENST00000554679 $(\mathrm{FC}=7.5$; associated mRNA RAD51B), were both confirmed to be significantly down-regulated in PD CLL. By RT-qPCR we were able to demonstrate that the associated mRNAs RALA and RAD51B were similarly differentially expressed, despite the lack of differential expression in the original mRNA microarray data (Figure 8B). The lncRNAs T204050 $(\mathrm{FC}=3.6), \mathrm{NR} 002947(\mathrm{FC}=8.3)$, and uc.436+ $(\mathrm{FC}=2.8)$ have known or nearby protein coding genes implicated in CLL biology [52-54]. RT-qPCR expression patterns of all 3 of these lncRNAs were consistent with the microarray data. With respect to the associated mRNAs, only CD79b was differentially expressed (up-regulated in PD) in the validation set (Figure 8C-8E).

\section{DISCUSSION}

In this study we identified 1,330 lncRNAs and 940 protein coding transcripts that were differentially expressed in a statistically significant manner between PD and ID Rai 0/I UM IGHV CLL using an array based method. We confirmed the differential expression of selected lncRNAs and their associated mRNAs by RT-qPCR including mRNAs that have previously been shown to play a role in CLL. The majority of differentially expressed lncRNAs and mRNAs had a $2-4$ FC with only $5.4 \%$ of the lncRNAs and $1.1 \%$ of mRNAs having a $\mathrm{FC} \geq 4.0$. Previous studies
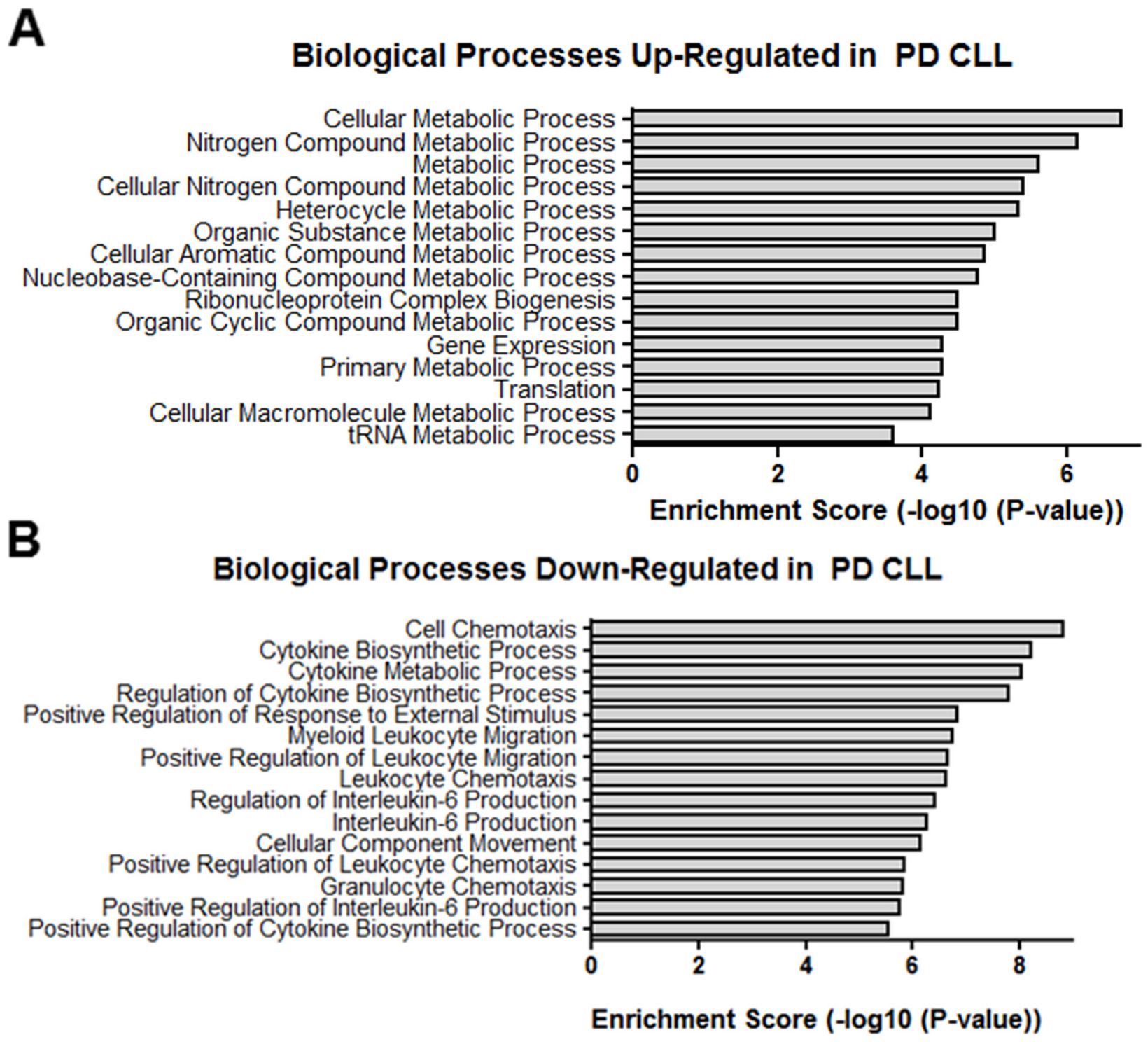

Figure 6: GO biological processes. Top GO biological processes enriched in (A) up-regulated transcripts and (B) down-regulated transcripts differentially expressed in PD vs ID CLL. 
of lncRNA expression during B cell development show that B cell subsets can be distinguished by their respective lncRNA pattern [34, 36, 55-57]. However, in our study we focused on a very stringent clinical and prognostic markerdefined subset of CLL (Rai stage 0/I UM IGHV) that was distinguished only by TTT and not compared to a normal cell counterpart nor a broader subset of aggressive CLL [45]. Therefore, it is expected that the overall differences in lncRNA expression are relatively subtle; however, our data demonstrate that distinct IncRNA expression patterns within this subset exist.

Of the 30 lncRNAs selected for validation by RTqPCR, 25 followed the directional trend of the microarray results with 20 reaching statistical significance by both methods. Seven lncRNAs were of particular interest based on high $\mathrm{FC}$ (T347014, $\mathrm{FC}=10.3$; T183853, $\mathrm{FC}=8.9$ ) or known associated or nearby protein coding genes previously linked to cancer (ENST00000435766; ENST00000554679) and specifically CLL (T204050; NR_002947; and uc.436+). The RT-qPCR results of the lncRNĀs were consistent with the microarray results. The lncRNAs T347014 and T183853 do not have known associated genes but T183853 does have a nearby coding gene, RNF144A, which has a role in regulating EGF/EGFR signaling and EGF dependent cell proliferation [58] suggesting that further evaluation of this lncRNA may be of value.

A

\section{Pathways Up-Regulated in PD CLL}

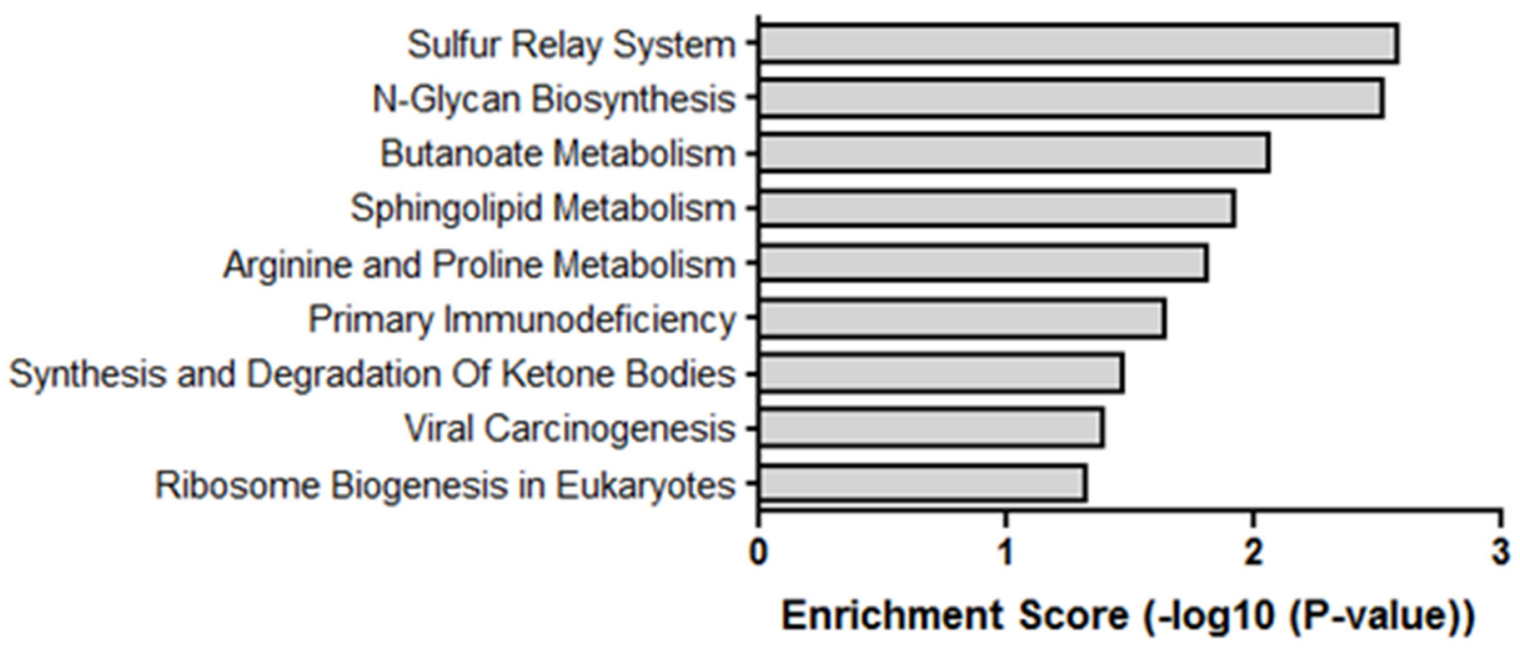

B

Pathways Down-Regulated in PD CLL

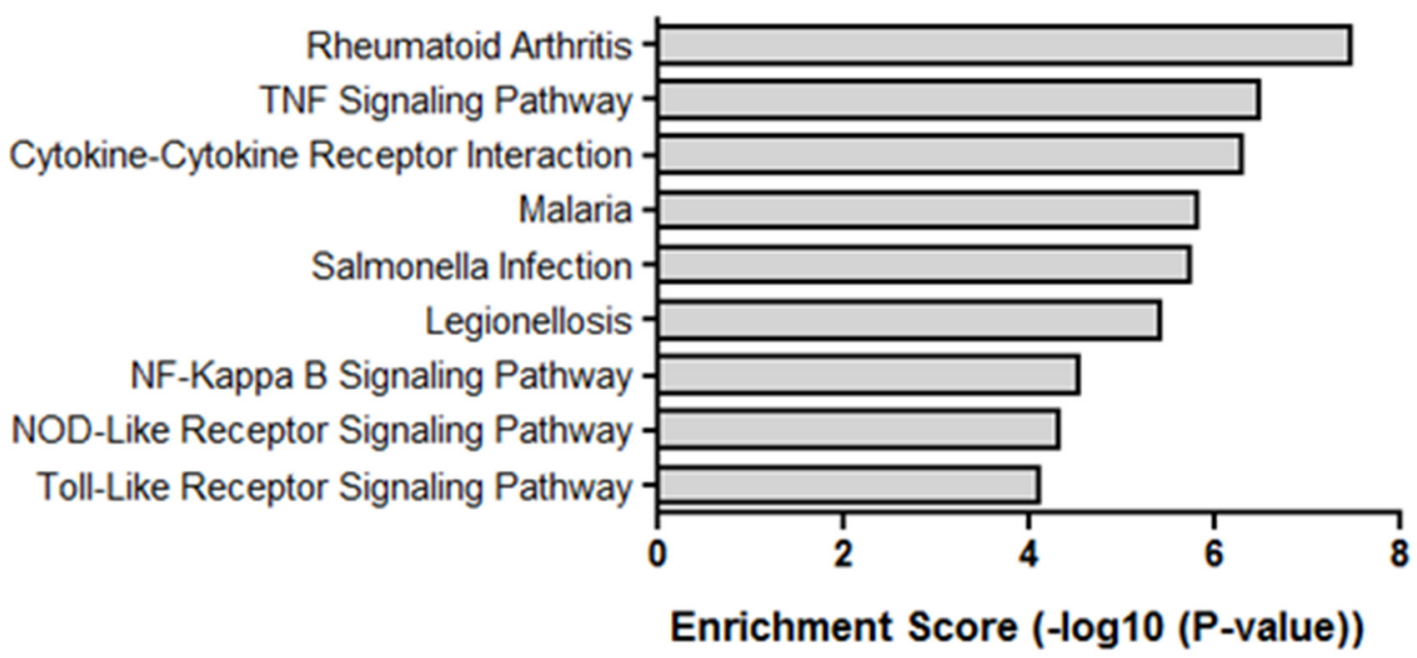

Figure 7: KEGG pathways. Enriched pathways in (A) up-regulated transcripts and (B) down-regulated transcripts differentially expressed in PD vs ID CLL. 
Table 3: IncRNAs and mRNAs selected for validation by RT-qPCR

\begin{tabular}{lccc}
\hline & IncRNA & \multicolumn{2}{c}{ Associated or Nearby mRNA } \\
\hline Sequence Name & $\begin{array}{c}\text { FC } \\
\text { (Microarray) }\end{array}$ & Gene Name & $\begin{array}{c}\text { FC } \\
\text { (Microarray) }\end{array}$ \\
\hline T347014 & 10.3; Down in PD & Not Identified & NA \\
T183853 & 8.9; Down in PD & RNF144A & NA \\
ENST00000435766 & 11; Down in PD & RAD51B & NS \\
ENST00000554679 & 7.5; Down in PD & CD49d & NS \\
T204050 & 3.6; Down in PD & CD79b & NS \\
NR_002947 & 8.3; Down in PD & TCF4 & $2.7 ;$ Up in PD \\
uc.436+ & 2.8; Up in PD & $2.2 ;$ Up in PD \\
\hline
\end{tabular}

Seven lncRNAs and 5 mRNAs of interest were selected for further validation by RT-qPCR. NA=Not assessed by microarray; $\mathrm{NS}=$ no statistically significant difference between PD and ID by microarray analysis.

The IncRNAs ENST00000435766 and ENST00000554679 have known associated protein coding genes which have been implicated in cancer. RALA (associated with ENST00000435766) is a GTPase and a downstream signaling molecule of RAS whose overexpression has been shown to result in malignant transformation and progression in chronic myelogenous leukemia. This effect can be attenuated by miR-181a, another type of non-coding RNA [59]. In this study, the lncRNA and RALA mRNA were overexpressed in the
A
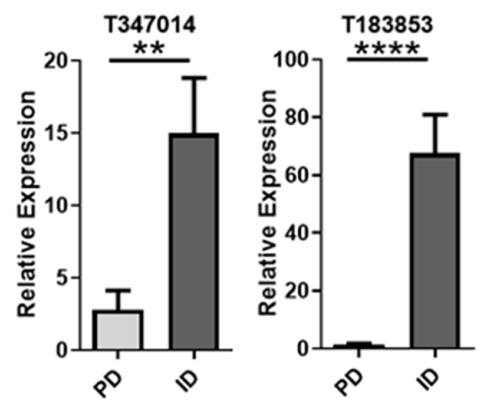

C
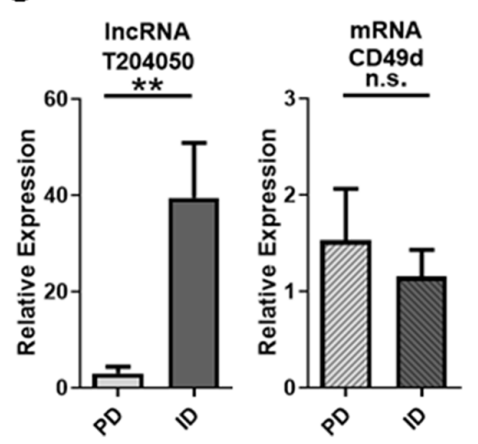

B
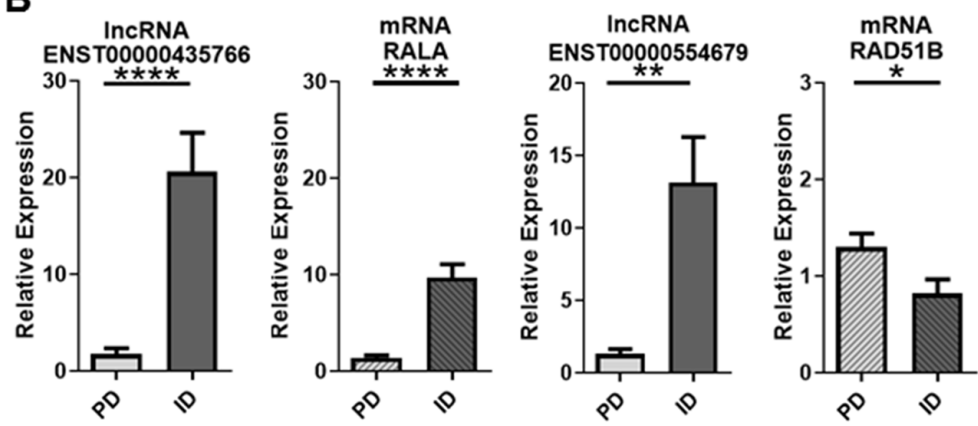

D

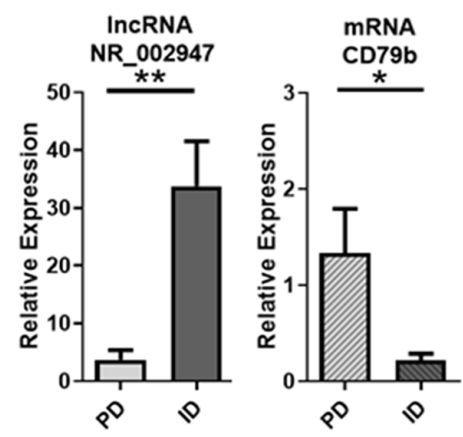

E

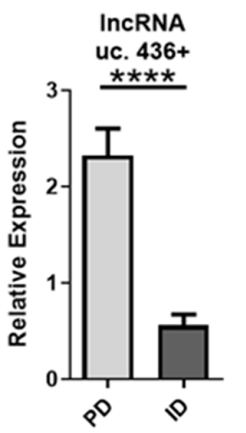

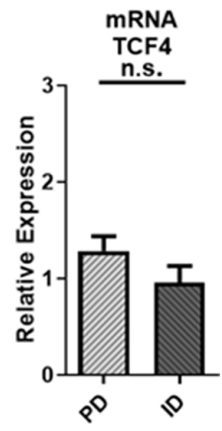

Figure 8: RT-qPCR validation of IncRNAs and associated mRNAs in PD vs ID CLL. (A) Significant down-regulation by the lncRNAs T347014 and T183853 was confirmed by RT-qPCR in an independent cohort of 10 samples (5 PD and 5 ID). (B) ENST00000435766 and ENST00000554679 were also down-regulated by RT-qPCR. Their associated mRNAs were not significantly differentially expressed by microarray analysis but differentially expressed by RT-qPCR. (C-E) lncRNAs with known associated mRNAs implicated in CLL had varying regulation patterns. Data are represented as mean +/- SEM; ${ }^{*} \mathrm{p}<0.05 ;{ }^{* *} \mathrm{p}<0.01 ;{ }^{* * *} \mathrm{p}<0.001 ;{ }^{* * * *} \mathrm{p}<0.0001$; n.s. $=$ not statistically significant (two-tailed $t$-test). 
indolent patient samples, suggesting the lncRNA and associated coding gene may have a different influence on disease pathogenesis in CLL.

RAD51B (associated with ENST00000554679) is a member of the RAD51 family of genes which play a role in homologous recombination and B-cell development [60]. In gastric cancer, RAD51B specifically has been identified as a potential biomarker for poor prognosis [61]. Furthermore, genetic variants in miR-binding sites of RAD51B have been shown to be associated with cervical cancer risk [62]. While germline mutations in RAD51B do not contribute to CLL [63], lack of IncRNA expression may be contributing to RAD51B expression and thus contributing to disease progression.

The lncRNA T204050 was down-regulated in PD by microarray analysis $(\mathrm{FC}=3.6)$ and $\mathrm{RT}-\mathrm{qPCR}$. Of interest, a nearby coding gene of the T204050 lncRNA is CD49d. We have previously shown that high expression of CD49d on CLL B-cells is a very strong prognostic indicator for aggressive CLL and is associated with shorter TTT [54]. In this scenario, the lncRNA T204050 was more highly expressed in ID CLL, but the associated mRNA for CD49d was not significantly differentially expressed but did follow a directional trend of being up-regulated in PD. However, as noted above, this is a very narrow clinical and prognostically defined subset of CLL and thus a larger cohort will be needed to further delineate if an IncRNA marker is associated with and impacting the expression of the negative prognostic marker CD49d [54].

Biologically relevant in CLL, the lncRNA NR 002947 and mRNA for its associated protein CD $79 \mathrm{~b}$ were found to be differentially expressed by both microarray and RT-qPCR and displayed opposite expression levels suggesting that $\mathrm{CD} 79 \mathrm{~b}$ expression may be altered by NR_002947. CD79b is a critical component of the B cell receptor and levels of CD79b mRNA have been shown to be higher in UM CLL even though surface expression of $\mathrm{CD} 79 \mathrm{~b}$ remains low [52]. However, Guo et al have shown that IL-4 restores CD79b protein expression at the post-transcriptional level and speculated that aberrant expression of micro-RNAs may be playing a role [64]. Those findings coupled with our results suggest that lncRNAs may be playing a role in the expression of $\mathrm{CD} 79 \mathrm{~b}$ and thereby affecting the B-cell receptor in CLL and further studies exploring this link are warranted.

The lncRNA uc.436+ is one of 481 segments longer than 200 base pairs first described by Bejerano et al [65] as being conserved with $100 \%$ identity between human, mouse and rat with no insertions or deletions. Calin et al [66] identified some of these regions as being involved in tumorigenesis, particularly human leukemias. While the IncRNA uc.436+ was not identified in Calin's studies, its nearby coding gene TCF4 is of particular interest in the context of CLL. The TCF/LEF proteins along with their transcriptional cofactor $\beta$-catenin are important components of the Wnt signaling pathway. We and others have shown that LEF-1 is aberrantly expressed in CLL B cells acting as a pro-survival factor and a possible marker for aggressive disease [53, 67-69]. Moreover, TCF4 has also been shown to be overexpressed in CLL B cells [70]. Both uc.436+ and TCF4 are significantly overexpressed in PD disease by microarray analysis and the TCF4 gene was found in 12 of the top 15 biological processes identified in our GO analysis of the up-regulated mRNAs in PD but was not identified in the biological processes downregulated in PD. Furthermore, we validated overexpression of uc.436+ in PD by RT-qPCR in an independent CLL cohort. While not significantly differentially expressed by RT-qPCR, TCF4 did show a directional trend towards being up-regulated in PD supporting further investigation of this lncRNA/mRNA association in PD vs ID CLL.

The IGHV mutation status in CLL has long been used as marker of disease progression with much more unfavorable disease kinetics for CLL clones expressing an UM IGHV. However the precise underlying mechanism for the association with biologically aggressive disease is still unknown. It was postulated at one time that CLL was two distinct diseases arising from B cells at different stages of maturation and therefore could account for the disparities in disease progression [71]. Gene expression profiling, however, found that all cases of CLL have a similar lineage independent of IGHV mutation status and indicated that all CLL B cells are more similar to postgerminal memory B cells [72]. Nonetheless, the great clinical variability in rates of disease progression in Rai 0/I UM IGHV CLL patients suggest undefined biological processes influencing progression. Previous studies have implicated lncRNAs in B cell development and lymphoma cell biology (reviewed in [36]), so it is feasible that $\operatorname{lncRNAs}$ may be playing a role in the progression among early stage UM IGHV CLL patients. Indeed, previous studies have found specific lncRNAs that may discriminate prognostic groups [44, 45]. In this study we show for the first time that even within a very specific clinical and prognostic subset of CLL, i.e., Rai 0/I UM IGHV CLL, both well annotated and novel lncRNAs are dysregulated and may be playing a role by altering expression of known associated or nearby genes involved in CLL pathogenesis. Further studies of specific lncRNA functions in CLL are warranted.

\section{MATERIALS AND METHODS}

\section{Patients and sample collection}

All patients provided written informed consent in accordance with the Declaration of Helsinki and the Mayo Clinic Institutional Review Board. The diagnosis of CLL required a B-cell count of $\geq 5 \times 10^{9} / \mathrm{L}$ along with a CD5+ and $\kappa$ or $\lambda$ monoclonal phenotype. For this study the cohort was restricted to Rai stage 0/I patients with UM IGHV $(\leq 2.0 \%$ deviation from the germline sequence 
$[12,13])$. To evaluate characteristics associated with rapid progression (PD) relative to those who had stable disease (ID) for many years, we identified 34 patients who experienced progression in $\leq 2$ years (TTT $\leq 2$ years) and a separate group who had not experienced progression in $\geq 5$ years (TTT $\geq 5$ years; $n=29$; Table 1 and Supplementary Table 1).

Peripheral blood from all study subjects was collected within 3 months of diagnosis and prior to any treatment. Mononuclear cells were collected by ficoll density gradient centrifugation (Ficoll-Paque Plus, GE Healthcare, Pittsburgh, PA, USA) and frozen until needed. RNA was isolated using the Trizol method (Life Technologies, Carlsbad, CA, USA) and quantitated on a NanoDrop 2000 spectrophotometer (Thermo Fisher Scientific, Waltham, MA, USA).

\section{Microarray and computational analysis}

RNA was submitted to Arraystar Inc. (Rockville, MD, USA) for IncRNA and mRNA expression profiling and data analysis. The Human lncRNA Array v4.0 covering 40,173 lncRNAs and 20,730 protein coding mRNAs was used. Sample preparation and hybridization were done according to Arraystar standard protocols. Agilent Feature Extraction software (Agilent Technologies, Santa Clara, CA, USA) was used to analyze array images and data analysis was done with GeneSpring GX v12.1 software (Agilent Technologies). After quantile normalization of the raw data, only those lncRNAs and mRNAs with at least 12 Present or Marginal flags were considered for further analysis. Volcano plot filtering identified lncRNAs and mRNAs with statistically significant differences between the 2 groups. Gene Ontology (GO) and Kyoto Encyclopedia of Genes and Genomes (KEGG) analyses were used to identify biological processes and pathway clusters associated with differentially expressed mRNAs. The p-value $(\leq 0.05)$ as calculated by the Fisher's exact test denotes the significance of the GO term in the list of differentially expressed mRNAs and the significant enrichment of differentially expressed mRNAs in biological pathways in the KEGG analysis. In both cases the enrichment score is the $-\log 10$ (p-value). The greater the enrichment score the more significant the pathway correlations. The complete set of lncRNA and mRNA data obtained in this study are available in the NCBI GEO database, accession number GSE123075.

\section{Real-time quantitative PCR validation}

Real-time quantitative PCR (RT-qPCR) was used to confirm the expression of selected lncRNAs and mRNAs in a subset of the microarray samples and in an additional validation set of 10 samples (5 PD and 5 ID). Expression was analyzed using SYBR green reagents (Qiagen, Germantown, MD, USA) on an ABI ViiA 7 Real-
Time PCR System (Thermo Fisher Scientific, Waltham, MA, USA). All RT-qPCR experiments were performed in triplicate and included no template controls. Data were analyzed by the $2^{\delta \delta \mathrm{Ct}}$ method against $\beta$-actin for normalization. Primers were designed with Primer-Blast (NCBI) and primer sequences are shown in Supplementary Table 2. Statistical analysis and graphic representation was performed using GraphPad Prism version 5.04 (GraphPad Software, Inc., La Jolla, CA, USA). Results were analyzed with the Student's t-test.

\section{Author contributions}

Contribution: R.C.T and D.F.J. designed the study and wrote the manuscript. R.C.T. performed the experiments and analyzed the data. T.D.S and N.E.K provided patient samples and assisted in writing the manuscript.

\section{ACKNOWLEDGMENTS}

We thank Drs. Denise Walters and Dominique Hoelzinger for helpful discussions of the data.

\section{CONFLICTS OF INTEREST}

The authors declare no potential conflicts of interest.

\section{FUNDING}

This work was supported by the National Institutes of Health (NIH) National Cancer Institute CA191380 (D.F.J.).

\section{REFERENCES}

1. Delgado J, Doubek M, Baumann T, Kotaskova J, Molica S, Mozas P, Rivas-Delgado A, Morabito F, Pospisilova S, Montserrat E. Chronic lymphocytic leukemia: A prognostic model comprising only two biomarkers (IGHV mutational status and FISH cytogenetics) separates patients with different outcome and simplifies the CLL-IPI. Am J Hematol. 2017; 92:375-80. https://doi.org/10.1002/ajh.24660.

2. International CLL-IPI working group. An international prognostic index for patients with chronic lymphocytic leukaemia (CLL-IPI): a meta-analysis of individual patient data. Lancet Oncol. 2016; 17:779-90. https://doi.org/10.1016/S1470-2045(16)30029-8.

3. Matutes E, Polliack A. Predicting time to first treatment in early stage CLL: scores, values and comparative prognostic models. Leuk Lymphoma. 2017; 58:1528-29. https://doi.org/10.1080/10428194.2017.1295149.

4. Parikh SA, Shanafelt TD. Prognostic factors and risk stratification in chronic lymphocytic 
leukemia. Semin Oncol. 2016; 43:233-40. https://doi.org/10.1053/j.seminoncol.2016.02.009.

5. Reda G, Cassin R, Fattizzo B, Giannarelli D, Mattiello V, Barcellini W, Cortelezzi A. Chronic lymphocytic leukemia and prognostic models: A bridge between clinical and biological markers. Am J Hematol. 2017; 92:E135-37. https://doi.org/10.1002/ajh.24755.

6. Yi S, Li Z, Zou D, An G, Cui R, Zhong S, Li H, Xiong W, Li C, Chen W, Liu W, Lv R, Yu Z, et al. Intratumoral genetic heterogeneity and number of cytogenetic aberrations provide additional prognostic significance in chronic lymphocytic leukemia. Genet Med. 2017; 19:18291. https://doi.org/10.1038/gim.2016.81.

7. Pflug N, Bahlo J, Shanafelt TD, Eichhorst BF, Bergmann MA, Elter T, Bauer K, Malchau G, Rabe KG, Stilgenbauer $\mathrm{S}$, Döhner H, Jäger U, Eckart MJ, et al. Development of a comprehensive prognostic index for patients with chronic lymphocytic leukemia. Blood. 2014; 124:49-62. https://doi.org/10.1182/blood-2014-02-556399.

8. Rose-Zerilli MJ, Gibson J, Wang J, Tapper W, Davis Z, Parker H, Larrayoz M, McCarthy H, Walewska R, Forster J, Gardiner A, Steele AJ, Chelala C, et al. Longitudinal copy number, whole exome and targeted deep sequencing of 'good risk' IGHV-mutated CLL patients with progressive disease. Leukemia. 2016; 30:1301-10. https://doi.org/10.1038/leu.2016.10.

9. Molica S, Giannarelli D, Mirabelli R, Levato L, Gentile M, Morabito F, Montserrat E. Reliability of six prognostic models to predict time-to-first-treatment in patients with chronic lymphocytic leukaemia in early phase. Am J Hematol. 2017; 92:E91-93. https://doi.org/10.1002/ajh.24707.

10. Mina A, Sandoval Sus J, Sleiman E, Pinilla-Ibarz J, Awan FT, Kharfan-Dabaja MA. Using prognostic models in CLL to personalize approach to clinical care: are we there yet? Blood Rev. 2018; 32:159-66. https://doi.org/10.1016/j.blre.2017.10.003.

11. Molica S, Shanafelt TD, Giannarelli D, Gentile M, Mirabelli R, Cutrona G, Levato L, Di Renzo N, Di Raimondo F, Musolino C, Angrilli F, Famà A, Recchia AG, et al. The chronic lymphocytic leukemia international prognostic index predicts time to first treatment in early CLL: independent validation in a prospective cohort of early stage patients. Am J Hematol. 2016; 91:1090-95. https://doi.org/10.1002/ajh.24493.

12. Damle RN, Wasil T, Fais F, Ghiotto F, Valetto A, Allen SL, Buchbinder A, Budman D, Dittmar K, Kolitz J, Lichtman SM, Schulman P, Vinciguerra VP, et al. Ig V gene mutation status and CD38 expression as novel prognostic indicators in chronic lymphocytic leukemia. Blood. 1999; 94:1840-47.

13. Hamblin TJ, Davis Z, Gardiner A, Oscier DG, Stevenson FK. Unmutated $\operatorname{Ig} \mathrm{V}(\mathrm{H})$ genes are associated with a more aggressive form of chronic lymphocytic leukemia. Blood. 1999; 94:1848-54.
14. Berndt SI, Camp NJ, Skibola CF, Vijai J, Wang Z, Gu J, Nieters A, Kelly RS, Smedby KE, Monnereau A, Cozen W, Cox A, Wang SS, et al. Meta-analysis of genome-wide association studies discovers multiple loci for chronic lymphocytic leukemia. Nat Commun. 2016; 7:10933. https://doi.org/10.1038/ncomms10933.

15. Law PJ, Berndt SI, Speedy HE, Camp NJ, Sava GP, Skibola CF, Holroyd A, Joseph V, Sunter NJ, Nieters A, Bea S, Monnereau A, Martin-Garcia D, et al. Genome-wide association analysis implicates dysregulation of immunity genes in chronic lymphocytic leukaemia. Nat Commun. 2017; 8:14175. https://doi.org/10.1038/ncomms14175.

16. Puente XS, Beà S, Valdés-Mas R, Villamor N, GutiérrezAbril J, Martín-Subero JI, Munar M, Rubio-Pérez C, Jares P, Aymerich M, Baumann T, Beekman R, Belver $\mathrm{L}$, et al. Non-coding recurrent mutations in chronic lymphocytic leukaemia. Nature. 2015; 526:519-24. https://doi.org/10.1038/nature14666.

17. Queirós AC, Villamor N, Clot G, Martinez-Trillos A, Kulis M, Navarro A, Penas EM, Jayne S, Majid A, Richter J, Bergmann AK, Kolarova J, Royo C, et al. A B-cell epigenetic signature defines three biologic subgroups of chronic lymphocytic leukemia with clinical impact. Leukemia. 2015; 29:598-605. https://doi.org/10.1038/leu.2014.252.

18. Djebali S, Davis CA, Merkel A, Dobin A, Lassmann T, Mortazavi A, Tanzer A, Lagarde J, Lin W, Schlesinger F, Xue C, Marinov GK, Khatun J, et al. Landscape of transcription in human cells. Nature. 2012; 489:101-08. https://doi.org/10.1038/nature11233.

19. Baltimore D, Boldin MP, O'Connell RM, Rao DS, Taganov KD. MicroRNAs: new regulators of immune cell development and function. Nat Immunol. 2008; 9:839-45. https://doi.org/10.1038/ni.f.209.

20. Calin GA, Ferracin M, Cimmino A, Di Leva G, Shimizu M, Wojcik SE, Iorio MV, Visone R, Sever NI, Fabbri M, Iuliano R, Palumbo T, Pichiorri F, et al. A MicroRNA signature associated with prognosis and progression in chronic lymphocytic leukemia. N Engl J Med. 2005; 353:1793-801. https://doi.org/10.1056/NEJMoa050995.

21. Cui B, Chen L, Zhang S, Mraz M, Fecteau JF, Yu J, Ghia EM, Zhang L, Bao L, Rassenti LZ, Messer K, Calin GA, Croce CM, Kipps TJ. MicroRNA-155 influences B-cell receptor signaling and associates with aggressive disease in chronic lymphocytic leukemia. Blood. 2014; 124:546-54. https://doi.org/10.1182/blood-2014-03-559690.

22. Ferreira PG, Jares P, Rico D, Gómez-López G, MartínezTrillos A, Villamor N, Ecker S, González-Pérez A, Knowles DG, Monlong J, Johnson R, Quesada V, Djebali $\mathrm{S}$, et al. Transcriptome characterization by RNA sequencing identifies a major molecular and clinical subdivision in chronic lymphocytic leukemia. Genome Res. 2014; 24:21226. https://doi.org/10.1101/gr.152132.112.

23. Mraz M, Chen L, Rassenti LZ, Ghia EM, Li H, Jepsen K, Smith EN, Messer K, Frazer KA, Kipps 
TJ. miR-150 influences B-cell receptor signaling in chronic lymphocytic leukemia by regulating expression of GAB1 and FOXP1. Blood. 2014; 124:84-95. https://doi.org/10.1182/blood-2013-09-527234.

24. Negrini M, Cutrona G, Bassi C, Fabris S, Zagatti B, Colombo M, Ferracin M, D’Abundo L, Saccenti E, Matis S, Lionetti M, Agnelli L, Gentile M, et al. microRNAome expression in chronic lymphocytic leukemia: comparison with normal B-cell subsets and correlations with prognostic and clinical parameters. Clin Cancer Res. 2014; 20:414153. https://doi.org/10.1158/1078-0432.CCR-13-2497.

25. Visone R, Veronese A, Rassenti LZ, Balatti V, Pearl DK, Acunzo M, Volinia S, Taccioli C, Kipps TJ, Croce CM. miR-181b is a biomarker of disease progression in chronic lymphocytic leukemia. Blood. 2011; 118:3072-79. https://doi.org/10.1182/blood-2011-01-333484.

26. Farazi TA, Hoell JI, Morozov P, Tuschl T. MicroRNAs in human cancer. Adv Exp Med Biol. 2013; 774:1-20. https://doi.org/10.1007/978-94-007-5590-1_1.

27. Grote P, Herrmann BG. Long noncoding RNAs in organogenesis: making the difference. Trends Genet. 2015; 31:329-35. https://doi.org/10.1016/j.tig.2015.02.002.

28. Isin M, Dalay N. LncRNAs and neoplasia. Clin Chim Acta. 2015; 444:280-88. https://doi.org/10.1016/j.cca.2015.02.046.

29. Schmitz SU, Grote P, Herrmann BG. Mechanisms of long noncoding RNA function in development and disease. Cell Mol Life Sci. 2016; 73:2491-509. https://doi.org/10.1007/s00018-016-2174-5.

30. Schwarzer A, Emmrich S, Schmidt F, Beck D, Ng M, Reimer C, Adams FF, Grasedieck S, Witte D, Käbler S, Wong JW, Shah A, Huang Y, et al. The non-coding RNA landscape of human hematopoiesis and leukemia. Nat Commun. 2017; 8:218. https://doi.org/10.1038/s41467-017-00212-4.

31. Guttman M, Russell P, Ingolia NT, Weissman JS, Lander ES. Ribosome profiling provides evidence that large noncoding RNAs do not encode proteins. Cell. 2013; 154:240-51. https://doi.org/10.1016/j.cell.2013.06.009.

32. Ruiz-Orera J, Messeguer X, Subirana JA, Alba MM. Long non-coding RNAs as a source of new peptides. eLife. 2014; 3:e03523. https://doi.org/10.7554/eLife.03523.

33. Brazão TF, Johnson JS, Müller J, Heger A, Ponting CP, Tybulewicz VL. Long noncoding RNAs in B-cell development and activation. Blood. 2016; 128:e10-19. https://doi.org/10.1182/blood-2015-11-680843.

34. Petri A, Dybkær K, Bøgsted M, Thrue CA, Hagedorn PH, Schmitz A, Bødker JS, Johnsen HE, Kauppinen S. Long Noncoding RNA Expression during Human B-Cell Development. PLoS One. 2015; 10:e138236. https://doi.org/10.1371/journal.pone.0138236.

35. Chen YG, Satpathy AT, Chang HY. Gene regulation in the immune system by long noncoding RNAs. Nat Immunol. 2017; 18:962-72. https://doi.org/10.1038/ni.3771.

36. Winkle M, Kluiver JL, Diepstra A, van den Berg A. Emerging roles for long noncoding RNAs in B-cell development and malignancy. Crit Rev Oncol Hematol. 2017; 120:77-85. https://doi.org/10.1016/j.critrevonc.2017.08.011.

37. Bhoi S, Baliakas P, Cortese D, Mattsson M, Engvall M, Smedby KE, Juliusson G, Sutton LA, Mansouri L. UGT2B17 expression: a novel prognostic marker within IGHV-mutated chronic lymphocytic leukemia? Haematologica. 2016; 101:e63-65. https://doi.org/10.3324/haematol.2015.136440.

38. Blume CJ, Hotz-Wagenblatt A, Hüllein J, Sellner L, Jethwa A, Stolz T, Slabicki M, Lee K, Sharathchandra A, Benner A, Dietrich S, Oakes CC, Dreger P, et al. p53-dependent non-coding RNA networks in chronic lymphocytic leukemia. Leukemia. 2015; 29:2015-23. https://doi.org/10.1038/leu.2015.119.

39. Fernando TR, Rodriguez-Malave NI, Waters EV, Yan W, Casero D, Basso G, Pigazzi M, Rao DS. LncRNA Expression Discriminates Karyotype and Predicts Survival in B-Lymphoblastic Leukemia. Mol Cancer Res. 2015; 13:839-51. https://doi.org/10.1158/1541-7786.MCR-15-0006-T.

40. Garzon R, Volinia S, Papaioannou D, Nicolet D, Kohlschmidt J, Yan PS, Mrózek K, Bucci D, Carroll AJ, Baer MR, Wetzler M, Carter TH, Powell BL, et al. Expression and prognostic impact of lncRNAs in acute myeloid leukemia. Proc Natl Acad Sci USA. 2014; 111:18679-84. https://doi.org/10.1073/pnas.1422050112.

41. Lammens T, Durinck K, Wallaert A, Speleman F, Van Vlierberghe P. Long non-coding RNAs in leukemia: biology and clinical impact. Curr Opin Hematol. 2017; 24:353-58. https://doi.org/10.1097/MOH.0000000000000354.

42. Melo CP, Campos CB, Rodrigues JO, Aguirre-Neto JC, Atalla Â, Pianovski MA, Carbone EK, Lares LB, Moraes-Souza H, Octacílio-Silva S, Pais FS, Ferreira AC, Assumpção JG. Long non-coding RNAs: biomarkers for acute leukaemia subtypes. Br J Haematol. 2016; 173:31820. https://doi.org/10.1111/bjh.13588.

43. Miller CR, Ruppert AS, Fobare S, Chen TL, Liu C, Lehman A, Blachly JS, Zhang X, Lucas DM, Grever MR, Tallman MS, Flinn IW, Rassenti LZ, et al. The long noncoding RNA, treRNA, decreases DNA damage and is associated with poor response to chemotherapy in chronic lymphocytic leukemia. Oncotarget. 2017; 8:25942-54. https://doi.org/10.18632/oncotarget.15401.

44. Ronchetti D, Manzoni M, Agnelli L, Vinci C, Fabris S, Cutrona G, Matis S, Colombo M, Galletti S, Taiana E, Recchia AG, Bossio S, Gentile M, et al. IncRNA profiling in early-stage chronic lymphocytic leukemia identifies transcriptional fingerprints with relevance in clinical outcome. Blood Cancer J. 2016; 6:e468. https://doi.org/10.1038/bcj.2016.77.

45. Sattari A, Siddiqui H, Moshiri F, Ngankeu A, Nakamura T, Kipps TJ, Croce CM. Upregulation of long noncoding RNA MIAT in aggressive form of chronic lymphocytic leukemias. Oncotarget. 2016; 7:54174-82. https://doi.org/10.18632/oncotarget.11099. 
46. Döhner H, Stilgenbauer S, Benner A, Leupolt E, Kröber A, Bullinger L, Döhner K, Bentz M, Lichter P. Genomic aberrations and survival in chronic lymphocytic leukemia. N Engl J Med. 2000; 343:1910-16. https://doi.org/10.1056/NEJM200012283432602.

47. Ma L, Bajic VB, Zhang Z. On the classification of long non-coding RNAs. RNA Biol. 2013; 10:925-33. https://doi.org/10.4161/rna.24604.

48. Vance KW, Ponting CP. Transcriptional regulatory functions of nuclear long noncoding RNAs. Trends Genet. 2014; 30:348-55. https://doi.org/10.1016/j.tig.2014.06.001.

49. Cuní S, Pérez-Aciego P, Pérez-Chacón G, Vargas JA, Sánchez A, Martín-Saavedra FM, Ballester S, García-Marco J, Jordá J, Durántez A. A sustained activation of PI3K/ NF-kappaB pathway is critical for the survival of chronic lymphocytic leukemia B cells. Leukemia. 2004; 18:1391400. https://doi.org/10.1038/sj.leu.2403398.

50. Foa R, Massaia M, Cardona S, Tos AG, Bianchi A, Attisano C, Guarini A, di Celle PF, Fierro MT. Production of tumor necrosis factor-alpha by B-cell chronic lymphocytic leukemia cells: a possible regulatory role of TNF in the progression of the disease. Blood. 1990; 76:393-400.

51. Muzio M, Fonte E, Caligaris-Cappio F. Toll-like Receptors in Chronic Lymphocytic Leukemia. Mediterr J Hematol Infect Dis. 2012; 4:e2012055.

52. Cajiao I, Sargent R, Elstrom R, Cooke NE, Bagg A, Liebhaber SA. Igbeta(CD79b) mRNA expression in chronic lymphocytic leukaemia cells correlates with immunoglobulin heavy chain gene mutational status but does not serve as an independent predictor of clinical severity. Am J Hematol. 2007; 82:712-20. https://doi.org/10.1002/ajh.20885.

53. Gutierrez A Jr, Tschumper RC, Wu X, Shanafelt TD, EckelPassow J, Huddleston PM 3rd, Slager SL, Kay NE, Jelinek DF. LEF-1 is a prosurvival factor in chronic lymphocytic leukemia and is expressed in the preleukemic state of monoclonal B-cell lymphocytosis. Blood. 2010; 116:297583. https://doi.org/10.1182/blood-2010-02-269878.

54. Shanafelt TD, Geyer SM, Bone ND, Tschumper RC, Witzig TE, Nowakowski GS, Zent CS, Call TG, Laplant B, Dewald GW, Jelinek DF, Kay NE. CD49d expression is an independent predictor of overall survival in patients with chronic lymphocytic leukaemia: a prognostic parameter with therapeutic potential. Br J Haematol. 2008; 140:53746. https://doi.org/10.1111/j.1365-2141.2007.06965.x.

55. Casero D, Sandoval S, Seet CS, Scholes J, Zhu Y, Ha VL, Luong A, Parekh C, Crooks GM. Long noncoding RNA profiling of human lymphoid progenitor cells reveals transcriptional divergence of B cell and $\mathrm{T}$ cell lineages. Nat Immunol. 2015; 16:1282-91. https://doi.org/10.1038/ni.3299.

56. Ranzani V, Rossetti G, Panzeri I, Arrigoni A, Bonnal RJ, Curti S, Gruarin P, Provasi E, Sugliano E, Marconi M, De Francesco R, Geginat J, Bodega B, et al. The long intergenic noncoding RNA landscape of human lymphocytes highlights the regulation of $\mathrm{T}$ cell differentiation by linc-MAF-4. Nat Immunol. 2015; 16:318-25. https://doi.org/10.1038/ni.3093.

57. Tayari MM, Winkle M, Kortman G, Sietzema J, de Jong D, Terpstra M, Mestdagh P, Kroese FG, Visser L, Diepstra A, Kok K, van den Berg A, Kluiver J. Long Noncoding RNA Expression Profiling in Normal B-Cell Subsets and Hodgkin Lymphoma Reveals Hodgkin and Reed-Sternberg Cell-Specific Long Noncoding RNAs. Am J Pathol. 2016; 186:2462-72. https://doi.org/10.1016/j.ajpath.2016.05.011.

58. Ho SR, Lin WC. RNF144A sustains EGFR signaling to promote EGF-dependent cell proliferation. J Biol Chem. 2018; 293:16307-23. https://doi.org/10.1074/jbc.RA118.002887.

59. Gu C, Feng M, Yin Z, Luo X, Yang J, Li Y, Li T, Wang R, Fei J. RalA, a GTPase targeted by miR181a, promotes transformation and progression by activating the Ras-related signaling pathway in chronic myelogenous leukemia. Oncotarget. 2016; 7:20561-73. https://doi.org/10.18632/oncotarget.7987.

60. Kim DR. Proteomic changes during the B cell development. J Chromatogr B Analyt Technol Biomed Life Sci. 2005; 815:295-303. https://doi.org/10.1016/j.jchromb.2004.07.036.

61. Cheng Y, Yang B, Xi Y, Chen X. RAD51B as a potential biomarker for early detection and poor prognostic evaluation contributes to tumorigenesis of gastric cancer. Tumour Biol. 2016; 37:14969-78. https://doi.org/10.1007/s13277-016-5340-3.

62. Hang D, Zhou W, Jia M, Wang L, Zhou J, Yin Y, Ma H, $\mathrm{Hu} \mathrm{Z}$, Li N, Shen H. Genetic variants within microRNAbinding site of RAD51B are associated with risk of cervical cancer in Chinese women. Cancer Med. 2016; 5:2596-601. https://doi.org/10.1002/cam4.797.

63. Sellick G, Fielding S, Qureshi M, Catovsky D, Houlston $\mathrm{R}$, and International Familial CLL Consortium. Germline mutations in RAD51, RAD51AP1, RAD51B, RAD51C,RAD51D, RAD52 and RAD54L do not contribute to familial chronic lymphocytic leukemia. Leuk Lymphoma. 2008; 49:130-33. https://doi.org/10.1080/10428190701606800.

64. Guo B, Zhang L, Chiorazzi N, Rothstein TL. IL-4 rescues surface IgM expression in chronic lymphocytic leukemia. Blood. 2016; 128:553-62. https://doi.org/10.1182/blood-2015-11-682997.

65. Bejerano G, Pheasant M, Makunin I, Stephen S, Kent WJ, Mattick JS, Haussler D. Ultraconserved elements in the human genome. Science. 2004; 304:1321-25. https://doi.org/10.1126/science.1098119.

66. Calin GA, Liu CG, Ferracin M, Hyslop T, Spizzo R, Sevignani C, Fabbri M, Cimmino A, Lee EJ, Wojcik SE, Shimizu M, Tili E, Rossi S, et al. Ultraconserved regions encoding ncRNAs are altered in human leukemias and carcinomas. Cancer Cell. 2007; 12:215-29. https://doi.org/10.1016/j.ccr.2007.07.027. 
67. Gutierrez A Jr, Arendt BK, Tschumper RC, Kay NE, Zent CS, Jelinek DF. Differentiation of chronic lymphocytic leukemia B cells into immunoglobulin secreting cells decreases LEF-1 expression. PLoS One. 2011; 6:e26056. https://doi.org/10.1371/journal.pone.0026056.

68. Jelinek DF, Tschumper RC, Stolovitzky GA, Iturria SJ, Tu Y, Lepre J, Shah N, Kay NE. Identification of a global gene expression signature of B-chronic lymphocytic leukemia. Mol Cancer Res. 2003; 1:346-61.

69. Wu W, Zhu H, Fu Y, Shen W, Miao K, Hong M, Xu W, Fan L, Young KH, Liu P, Li J. High LEF1 expression predicts adverse prognosis in chronic lymphocytic leukemia and may be targeted by ethacrynic acid. Oncotarget. 2016; 7:21631-43. https://doi.org/10.18632/oncotarget.7795.

70. Gutierrez A, Tschumper R, Eckel-Passow J, Kay NE, Jelinek DF. Overexpression of the LEF-1 and TCF4
Transcription Factors in B-CLL. Further Evidence for a Role of the Wnt Signaling Pathway in B-CLL Biology and Leukemogenesis. Blood. 2008; 112:544.

71. Stilgenbauer S, Bullinger L, Lichter $\mathrm{P}$, Döhner $\mathrm{H}$, and German CLL Study Group (GCLLSG). Chronic lymphocytic leukemia. Genetics of chronic lymphocytic leukemia: genomic aberrations and $\mathrm{V}(\mathrm{H})$ gene mutation status in pathogenesis and clinical course. Leukemia. 2002; 16:993-1007. https://doi.org/10.1038/sj.leu.2402537.

72. Klein U, Tu Y, Stolovitzky GA, Mattioli M, Cattoretti G, Husson H, Freedman A, Inghirami G, Cro L, Baldini L, Neri A, Califano A, Dalla-Favera R. Gene expression profiling of $\mathrm{B}$ cell chronic lymphocytic leukemia reveals a homogeneous phenotype related to memory B cells. J Exp Med. 2001; 194:1625-38. https://doi.org/10.1084/jem.194.11.1625. 